\title{
Obituary: Stanley Marion Garn (1922-2007)
}

\author{
B. Holly Smith, ${ }^{1 \star}$ A. Roberto Frisancho, ${ }^{2}$ and Stephen M. Bailey ${ }^{3}$ \\ ${ }^{1}$ Museum of Anthropology, The University of Michigan, Ann Arbor, MI 48109 \\ ${ }^{2}$ Department of Anthropology, The University of Michigan, Ann Arbor, MI 48109 \\ ${ }^{3}$ Department of Anthropology, Tufts University, Boston, MA 02155
}

Stanley Marion Garn, 84, Professor Emeritus of Nutrition in the School of Public Health, Professor Emeritus of Anthropology in the College of Literature, Science and Arts, and Emeritus Fellow in the Center for Human Growth and Development, died August 31, 2007 in Ann Arbor, Michigan of complications from peripheral vascular disease.

Born October 27, 1922 in New London, Connecticut, Stanley Garn (Fig. 1) was a prolific author and researcher, authority on human biology, and a key figure in physical anthropology of the 20th century. He served as president of the American Association of Physical Anthropologists 1965-1967. He was elected to the U.S. National Academy of Sciences in 1976, and in 1988, the AAPA honored him with the Charles R. Darwin Lifetime Achievement Award. In 2002, The Human Biology Council selected him for their Franz Boas award.

\section{NEWSPAPER CORRESPONDENT}

"I have always written" begins a short memoir Stanley wrote for his children. ${ }^{1}$ An early facility with prose and a quick wit were perfect tools for a writing career that began with his Providence R.I. high school newspaper, "The Classical Review," where he wrote multiple articles under various bylines. At Harvard, while still only 17, he was simultaneously the "Harvard correspondent" for three papers (the morning Daily Record, the afternoon Boston American, and the Record American Sunday Adventurer), making 25 cents per column inch. Since headlines and photos counted, he learned to design his stories for interest and maximum type size and to produce regular copy on a deadline.

\section{HARVARD WITH COON AND HOOTON}

As a Harvard freshman, he had no interest in anthropology, but he needed a course to fill M W F at $10 \mathrm{am}$, and Carleton Coon's Anthropology 1A filled the bill. It required instructor's permission. When Coon opened the door and saw Stanley, he pronounced: "You are Sephardic!" Stanley remembered that as a pretty neat trick and worth some investigation. Coon was a captivating lecturer and his course a revelation of the greater world to Stanley, a boy from Providence who had only once been as far as New York City. "We went all over the world, in lectures and slides, we saw all kinds of people, including Negritos and Negrillos. It was something like an illus-

\footnotetext{
${ }^{1}$ Garn SM. "I have always written (1934-1944)" nine pages handwritten, dated October 1997.
}

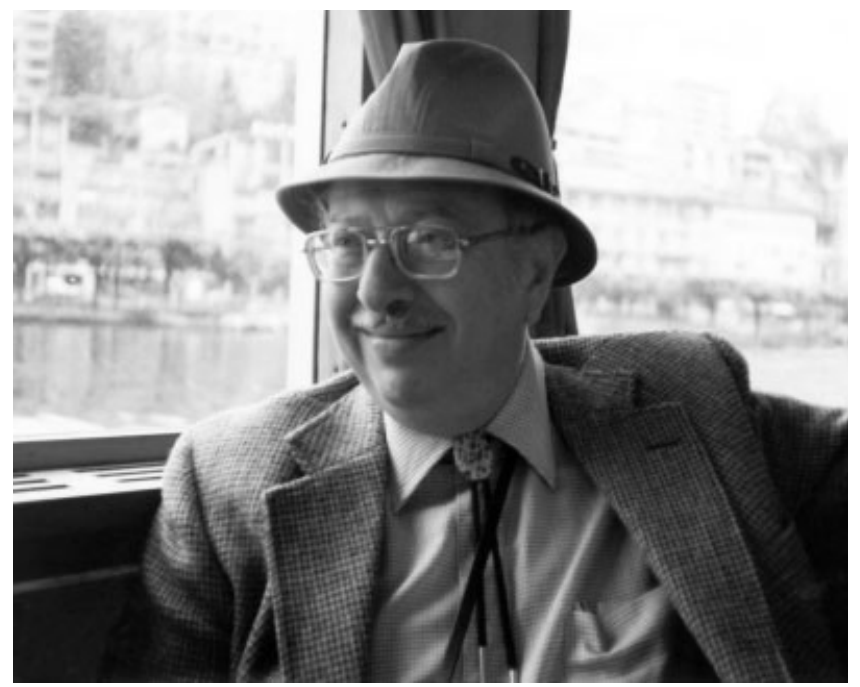

Fig. 1. Stanley Garn on a train in Italy in 1980.

trated, animated National Geographic."2 By his sophomore year, he was an anthropology concentrator, electing Coon as his tutor. Sometime after Pearl Harbor, however, Coon disappeared into the OSS, and Garn transferred to E. A. Hooton. Garn developed a close relationship with Hooton, attending, although an undergraduate, Hooton's Saturday afternoon teas (Garn and Giles, 1954). Hooton's cohort of students would go on to found most of the country's Ph.D. programs in physical anthropology (see Spencer, 1982). With Hooton as his tutor, Stanley finished his senior thesis "Anomalies, Varieties,

\footnotetext{
${ }^{2}$ Garn SM. "How I became an anthropologist" nine pages hand-
} written, dated 9/29/1997.

Additional Supporting Information may be found in the online version of this article.

*Correspondence to: B. Holly Smith, Museum of Anthropology, The University of Michigan, Ann Arbor, MI 48109, USA.

E-mail: bhsmith@umich.edu

Received 10 November 2008; accepted 11 November 2008

DOI 10.1002/ajpa.20996

Published online 23 January 2009 in Wiley InterScience (www.interscience.wiley.com). 
and Pathology of the Dentition with References to Anthropological Study" in the summer of 1942 to graduate with an $\mathrm{AB}$ in anthropology.

Brace (2008) gives a thorough chronology of Garn's career and appointments. There was, apparently, a foray into law school, quickly abandoned for work more to his interest. During the war years 1942-1944, Garn was photographer-photomicrographer at the Chemical Warfare Service of the Massachusetts Institute of Technology, where he also helped design gas masks to fit the variety of faces of service men and women. Finally convinced he could make a living as an anthropologist, Garn entered graduate school as a Hooton student, at first part time, becoming full time after a 1946-1947 stint as a technical editor and consultant on face anthropometry at the Polaroid Corporation. After gaining his credentials (AM 1947 and Ph.D. 1948) with his dissertation "Human Hair; Its Composition, Anatomy and Distribution," he continued as a lecturer at Harvard.

\section{RESEARCH FELLOW}

Two part time research positions would lead to many scientific contributions. The first (1946-1950) was as Research Fellow in Medicine at Massachusetts General Hospital to work on coronary artery disease with Menard Gertler and Paul Dudley White. Garn worked on a series of papers (Gertler et al., 1950a,b; Garn et al., 1951a,b) and a classic text (Gertler et al., 1954) on determinants of CAD including serum cholesterol, the cholesterol/phospholipid ratio, uric acid, diet, somatotype, body weight, smoking, and age. The group's work did much to establish atherosclerosis as a disease rather than a natural consequence of aging (Friedlich, 1994).

His second position was as Research Fellow in Anthropology at the Forsyth Dental Infirmary (1947-1952). In 1947, Coenraad Moorrees also accepted a position at Forsyth as Senior Research Fellow in Orthodontics, and the two would make fundamental contributions to dental anthropology and basic knowledge of dental development. In the summer of 1948, at Hooton's urging, Moorrees accompanied Garn and others on primary field research in the Aleutian Islands on the Harvard Peabody Museum medical and anthropological expedition (led by Bill Laughlin). Garn's Aleut experience contributed both to a paper on Aleut serum cholesterol (Garn and Gertler, 1951) and tooth emergence (Garn and Moorrees, 1951). His friendship with Moorrees would last a lifetime: Garn and Moorrees would recall chasing seal pups over ice to get their cardiograms (see Moorrees, 1957), and met regularly when the Garns returned to Boston.

\section{MARRIAGE}

Garn married Priscilla Crozier in 1950. Priscilla, who was a gifted artist, was the daughter of the Harvard physiologist W.J. Crozier. Their best man was Ed Hunt, Garn's dear friend and fellow Hooton student. Priscilla's younger half-sister Mary Louise later married C. Loring Brace, making the two colleagues (both at University of Michigan after 1968) brothers-in-law. Stanley and Priscilla Garn had two children, Barbara and William Garn, now of San Luis Obispo California. Priscilla Crozier Garn died a few months after her husband on January $26,2008$.

\section{FELS AND ANTIOCH}

In 1952 Garn joined the Department of Physical Growth and Genetics at the Fels Research Institute in Yellow Springs, Ohio, where he became responsible for what became the largest and longest continuous study of human growth in the world. A simultaneous appointment in the Anthropology Department at Antioch College gave him contacts with students, including a young Stephen J. Gould.

Garn's 16 years at Fels formed the apex of his career. For the first time, he could marshal resources sufficient to exercise his three research themes at once: human growth and maturation, population differences in epidemiological risk, and family line studies. At Fels, Garn produced landmark studies of fat and fat patterning (e.g., 1955; Garn and Haskell, 1959), and the life history of bone mineralization from infancy to old age (especially Garn et al., 1967b,c). Garn and his Fels colleagues set the analysis of tooth formation on the right track (Garn et al., 1958). Collaboration with A. B. Lewis (many with R. S. Kerewsky also) would lead to fundamental studies of genetic vs. environmental signatures in tooth calcification and eruption, crown size, and sexual dimorphism (particularly Garn et al., 1965a,b,c, 1967a, 1968a,b). Garn and Lewis became, along with their friends, Albert Dahlberg and Coenraad Moorrees, seminal figures in dental anthropology.

Garn's considerable practical skills let him move easily from research to shop or laboratory. All his life, if something was needed to provide a new measurement, he could design and often fabricate it, whether it involved nose form, breast size, body composition, or epiphyseal fusion and determine how best to photograph, radiograph, or illustrate it. Garn also had a talent for basic statistics and developed an unmatched understanding of the uses and pitfalls of growth data. Throughout his career, he published on instruments, methods, statistics, and photography.

\section{HUMAN RACES}

While at Fels, Garn also wrote "Human Races" (1961), which marks an important transition between the physical anthropology of race of the first and second parts of the 20th century. Garn had absorbed encyclopedic information on human diversity from Hooton and Coon, and the book highlights the shallow knowledge reflected in lay concepts of race. Its genesis can be seen in Garn and Coon (1955), which tries to reconcile racial anthropology with the modern synthesis of Dobzhansky, Simpson, and Mayr. "Human Races" is probably most often cited for its taxonomy of nine major geographic races, 32 representative local races, and "thousands" of "microraces," which corresponded to breeding populations. The book's heart, however, concerns the distribution of genetic markers in local or breeding populations such as hemoglobinopathies and haptoglobins, Tay Sachs and b-amino isobutyric acid, and more complex conditions such as cortical bone apposition, coronary artery disease, and diabetes, for which Garn emphasized the interaction of genotype with environment. With characteristic humor, Garn admonished against essentialist typologies ${ }^{3}$ and their

\footnotetext{
3"Blue eyes and blond hair are no more proof for an original Nordic race than ... short stature and heavy beards (point) to a race of Trolls." (Garn, 1961, p 5).
} 
dubious applications ${ }^{4}$ while he attempted to put race in a context of geographic variation, natural selection, and evolution.

Earlier, as editor of "Readings on Race" (1960) Garn included Livingstone's seminal paper on sickle cell gene distribution, Crenshaw's critique of Coon's "candelabra" model of racial evolution, and Johnson's dismissal of schemes that linked living populations to paleospecies as "an exercise in futility." Yet after this point, physical anthropology increasingly signed on to Livingstone's (1962, p 279) view that "there are no races, there are only clines," culminating in the AAPA statement on race (1996, p 568-570) that relies on the terms "population" and the innocuous "group." Garn himself felt that post1960 anthropology largely avoided the topic by such substitutions (see Garn, 1982).

Ironically, recent biomedical approaches to variation now sort haplotypes, single nucleotide polymorphisms, and copy number variants into dendritic "clusters" with either geographic or population names often identical to Human Races' geographic or local races (e.g., Jakobsson et al., 2008). How systems of recognizing human variation map onto each other-geographic/phenotypic/social versus blood proteins and DNA-continues to spark both interest and debate (e.g., Bamshad and Olson, 2003; Long and Kittles, 2003; Marks, 2007).

Even as "Human Races" went through three editions and nine printings in multiple languages, Garn's own research, from his stewardship of the Fels Longitudinal Study through his involvement with the Ten State Nutrition Study and the Tecumseh Total Population Study, became ever more allied with epidemiology and human biology. Race kept a place in Garn's later research as one of the epidemiological factors (racial, familial, economic, and nutritional) that affected bone and tooth development, anthropometrics, fatness, serum biochemistry, fetal development, pregnancy, or birth weight of Americans.

\section{HUMAN BIOLOGY AT THE UNIVERSITY OF MICHIGAN}

The University of Michigan Center for Human Growth and Development recruited Garn in the late 1960s, uniting him with colleagues with similar interests and a steady supply of eager graduate students. During his tenure at the University of Michigan, from 1968 to his retirement in 1992, Garn's productivity was legendary. His combination of wit, writing skill, practical know how, experience, and a daily writing habit were ideal for an academic. His review articles were often tours de force (e.g., Garn, 1977, 1981, 1985; Garn and Bailey, 1978), additionally revealing the inadequacy of the "et al." convention-defying one's efforts to locate "Garn et al. 1967f" in "literature cited." Another book, "The Earlier Gain and the Later Loss of Cortical Bone" (1970) was widely influential.

Most of Garn's research output treats obesity and nutrition, growth and development, or bone and dental/facial topics. Yet, he was also an authority on radiography and

\footnotetext{
4"As a matter of opinion, backed by some personal experience with mental test data, one may question whether it took more brains to succeed in Neolithic Ireland or in the Indus Valley ... [or] whether it takes more "intelligence" to survive in Kansas City than in the Kalahari” (Garn, 1961, p 114).
}

clinical photography of human subjects (Garn et al., 1964) and the diagnosis of dysmorphology (Gall et al., 1972; Poznanski et al., 1972). In the 1980s, he marshaled the evidence for pregnancy outcomes in maternal smoking (Garn, 1980, 1985). He could always write a paper that called out to be read: "The noneconomic nature of eating people" (Garn, 1979) or "Was the ill-fated Franklin Expedition a victim of lead poisoning?" (Garn, 1989). As befits such command, Garn's last published article (1998) linked a classic anthropometric concept (fat patterning) with current biomedical research on leptin and body fat.

Garn's lifetime bibliography is too lengthy to reprint here. Some 383 publications are currently available through PubMed (http://www.ncbi.nlm.nih.gov/sites/ entrez) in the Library of Congress. However, a more complete list provided in Supporting Information online, including books, brief communications, letters to the editors, and articles published in symposia or edited books (excluding in-house publications and reports to funding agencies) amounts to over 800 publications.

\section{AS AN EDUCATOR AND COLLEAGUE}

In his heyday at Michigan, Garn had a secretary and up to four research assistants at a time. A creature of habit, Garn wheeled down the hallway every morning calling out "Greetings!" and handed the secretary the previous evening's pages, hand-written on yellow lined paper. In the office, he dictated the morning memos for research assistants and drafts of research papers with the assistant concerned sitting in. One such memo (in B. $\mathrm{H}$. Smith's memory) had 17 points, ending with "... then go back to the beginning and do it the other way."

Garn was a hands-on teacher, who instructed graduate students in every aspect of scientific research and publication. He was unfailingly enthusiastic about science and research, and generous with his time and attention. Working for Garn was an apprenticeship with a master craftsman: he taught students how to develop an idea, measure an effect, analyze it, illustrate it, document the work, write it up, and package it with a cover letter. He was an unfailing source of practical advice for future academics. Among the suggestions, we remember is being advised not to "wing it" at important occasions (Garn said he had seen even senior scientists spout offthe-cuff gibberish); that it was essential to write only constructive reviews of other's work; and that figures and legends should tell the story of the paper-most people's legends were like describing a photo of a Playboy bunny as "colored dots on white paper." Garn encouraged excellence in public speaking: "If you do not entertain yourself when you teach," he once said, pausing for the appropriate number of beats, "you will never entertain your audience." His own papers, we could see, attracted large audiences no less for their clarity and humor than for their content.

Of course, as colleagues recall, you could equally ask Garn how to fix a furnace, choose film stock, adjust ill-fitting glasses, plant your garden, or invest your money-his breadth was astonishing. In casual conversation, Garn's mind was so quick that his discourse sometimes confused people. Friends and colleagues knew that "Garn speak" required one's complete attention to appreciate its jumps, puns, and references. His own style as a colleague was positive; he never wasted breath on complaint or competitors. As Alex Roche, Garn's colleague and successor at Fels recalls: "I do not recall a 
single adverse comment he made about another person ... [nor was there] any occasion when a staff member made a negative remark about Stanley" after he left for Michigan. Roche adds, "Stanley was regarded highly by all who knew him partly because he was so accessible and helpful to junior and senior colleagues... He had an extraordinary range of interests and great ability to peruse data and recognize associations and trends that were justified and easily understood after he had directed attention to them."

Garn was unfailingly generous at sharing authorship with junior colleagues and his research assistants, who garnered substantial bibliographies while still students. At a luncheon celebrating his 600th publication, his research assistants fondly presented him with a cake that read:

To Dr. Garn

from the et al.s

\section{ACKNOWLEDGMENTS}

The authors thank Barbara and Bill Garn for sharing photographs and their father's memoir. They thank colleagues who contributed memories or comments: Lassie Alvesalo, Al Burdi, Pat Cole Hinton, Bob Hinton, Jules Kieser, Clark Larsen, Marquisa LaVelle, Alex Roche, and Karen Rosenberg. Alex Roche and Michael Little commented on the text. They also thank Sheba Shakir for preparing the online bibliography.

\section{LITERATURE CITED}

American Association of Physical Anthropologists. 1996. AAPA Statement on biological aspects of race. Am J Phys Anthropol 101:568-570.

Bamshad MJ, Olson SE. 2003. Does race exist? Sci Am 289:78-85.

Brace CL. 2008. Stanley Marion Garn. N Acad Sci Biogr Mem p 1-13.

Friedlich AL. 1994. Review of: coronary heart disease in young adults: a multidisciplinary study, by Gertler et al. (a 40th year anniversary of its original publication). N E J Med 331:207.

Gall JC Jr, Hayward JR, Harper ML, Garn SM. 1972. Studies of dysmorphogenesis in children with oral clefts. I. Relationship between clinical findings and school performance. Cleft Palate J 9:326-334.

Garn SM. 1955. Relative fat patterning: an individual characteristic. Hum Biol 27:75-89.

Garn SM, editor. 1960. Readings on race. Springfield: CC Thomas.

Garn SM. 1961. Human races. Springfield: CC Thomas.

Garn SM. 1970. The earlier gain and the later loss of cortical bone. Springfield: CC Thomas.

Garn SM. 1977. Genetics of dental development. In: McNamara JA, editor. The biology of occlusal development. Ann Arbor: Center for Human Growth and Development. p 61-88.

Garn SM. 1979. The noneconomic nature of eating people. Am Anthropol 81:902-903.

Garn SM. 1980. Tell pregnant patients: do not smoke! Med Times 108:18s-30s.

Garn SM. 1981. Contributions of the radiographic image to our knowledge of human growth. Am J Roentgen 137:231-239.

Garn SM. 1982. Comment on: redefining race: the potential demise of a concept in physical anthropology, by Littlefield A, Lieberman L, and Reynolds LT. Curr Anthropol 23:649.

Garn SM. 1985. Smoking and human biology. Hum Biol 57:505-523.

Garn SM. 1989. Was the ill-fated Franklin expedition a victim of lead poisoning? Nutr Rev 47:322-323.

Garn SM. 1998. Serum leptin concentration influenced by fat placement. Am J Clin Nutr 67:755-756.

Garn SM, Bailey SM. 1978. Genetics of maturational processes. In: Falkner F, Tanner JM, editors. Human growth, Vol. 1. New York: Plenum. p 307-330.
Garn SM, Coon C. 1955. On the number of races of mankind. Am Anthropol 57:996-1001.

Garn SM, Gertler MM. 1951. Age and sex differences in the serum cholesterol of the Aleut. Can Med J 64:338-340.

Garn SM, Gertler MM, Levine SA. 1951a. Serum uric acid in relation to age and physique in health and in coronary heart disease. Ann Intern Med 34:1421-1431.

Garn SM, Gertler MM, Levine SA, White PD. 1951b. Body weight versus weight standards in coronary artery disease and in a healthy group. Ann Intern Med 34:1416-1420.

Garn SM, Giles E. 1954. Earnest Albert Hooton. N Acad Sci Biogr Mem 68:167-179.

Garn SM, Haskell JA. 1959. Fat and growth during childhood. Science 130:1711-1712.

Garn SM, Lewis AB, Blizzard RM. 1965a. Endocrine factors in dental development. J Dent Res 44:243-258.

Garn SM, Lewis AB, Kerewsky RS. 1965b. Genetic, nutritional, and maturational correlates of dental development. J Dent Res 44:228-242.

Garn SM, Lewis AB, Kerewsky RS. 1968a. The magnitude and implications of the relationship between tooth size and body size. Arch Oral Biol 13:129-131.

Garn SM, Lewis AB, Polacheck DL. 1958. Variability of tooth formation in man. Science 128:1510.

Garn SM, Lewis AB, Swindler DR, Kerewsky RS. 1967a. Genetic control of sexual dimorphism in tooth size. J Dent Res Suppl 46:963-972.

Garn SM, Lewis AB, Vicinus JH. 1965c. Third molar polymorphism and its significance to dental genetics. Yearb Phys Anthropol 11:257-277.

Garn SM, Lewis AB, Walenga AJ. 1968b. Crown-size profile pattern comparisons of 14 populations. Arch Oral Biol 13:12351242.

Garn SM, Moorrees CFA. 1951. Stature, body build and tooth emergence in the Aleutian Aleut. Child Dev 22:262-270.

Garn SM, Rohmann CG, Silverman FN. 1967b. Radiographic standards for postnatal ossification and tooth calcification. Med Radiogr Photogr 43:45-66.

Garn SM, Rohmann CG, Wagner B. 1967c. Bone loss as a general phenomenon in man. Fed Proc 26:1729-1736.

Garn SM, Silverman FN, Davis AA. 1964. Gonadal dosages in investigative radiography. Science 143:1039.

Gertler MM, Garn SM, Lerman J. 1950a. The interrelationships of serum cholesterol, cholesterol esters and phospholipids in health and in coronary artery disease. Circulation 2:205-214.

Gertler MM, Garn SM, White PD. 1950b. Diet, serum cholesterol and coronary artery disease. Circulation 2:696-704.

Gertler MM, White PD, Bland EF, Fertig J, Garn SM, Lerman J, Levine SA, Sprague HB, Turner MC. 1954. Coronary heart disease in young adults. Cambridge: Harvard University Press.

Jakobsson M, Scholz SW, Scheet P, Gibbs JR, VanLiere JM, Fung H-C, Szpiech ZA, Degnan JH, Wang K, Guerreiro R, Bras JM, Schymick JC, Hernandez DG, Traynor BJ, SimonSanchez J, Matarin M, Britton A, Leemput J, Rafferty I, Bucan M, Cann HM, Hardy JA, Rosenberg NA, Singleton AB. 2008. Genotype, haplotype and copy-number variation in worldwide human populations. Nature 451:998-1003.

Livingstone FB. 1962. On the non-existence of human races. Curr Anthropol 3:279-281.

Long JC, Kittles RA. 2003. Human genetic diversity and the non-existence of biological races. Hum Biol 75:449-471.

Marks J. 2007. Human biological diversity. In: Middleton J, Miller J, editors. New encyclopedia of Africa, Vol. 2. New York: Charles Scribner's Sons. p 620-624.

Moorrees CFA. 1957. The Aleut dentition: a correlative study of dental characteristics in an Eskimoid people. Cambridge: Harvard University Press.

Poznanski A, Garn SM, Nagy JM, Gall JC Jr. 1972. Metacarpophalangeal pattern profiles in the evaluation of skeletal malformations. Radiology 104:1-11.

Spencer F. 1982. Introduction. In: Spencer F, editor. A history of American physical anthropology 1930-1980. New York: Academic Press. p 1-10. 